\title{
KRITERIA DIAGNOSIS DAN DIAGNOSIS BANDING SUDDEN DEAFNESS (SSNHL)
}

\author{
Arvindan Subramaniam \\ ${ }^{1}$ Program Studi Pendidikan Dokter, Fakultas Kedokteran Universitas Udayana \\ (dr.arvindan@gmail.com)
}

\section{ABSTRAK}

Pendahuluan:Tuli mendadak atau sudden deafness atau sudden sensorineural hearing loss (SSNHL) didefinisikan sebagai kehilangan pendengaran sensorineural yang lebih dari $30 \mathrm{~dB}$ pada 3 frekuensi berturut turut dalam onset 3 hari, sering unilateral dan bersifat idiopatik. Etiologi tuli mendadak masih belum diketahui secara pasti namun terdapat banyak teori yang dikemukakan oleh para ahli sebagai faktor resiko terjadinya tuli mendadak. Prevalensi tuli mendadak 5-30 tiap 100.000 orang pertahun. Distribusi laki-laki dan perempuan hampir sama, dengan puncak usia 50-60 tahun.Diagnosis tuli mendadak ditegakkan berdasarkan anamnesis, pemeriksaan fisik dan audiometri. Tuli mendadak mempunyai tiga karakteristik yaitu bersifat akut, tuli sensorineural dan etiologi tidak diketahui.Karakteristik tambahan dapat berupa vertigo, tinitus dan tidak adanya keterlibatan saraf kranialis. Penatalaksanaan tuli mendadak meliputi terapi konservatif dengan beberapa modalitas.

Kasus:Penderita laki-laki, 40 tahun, suku Bali, beragama Hindu datang dengan keluhan utama pendengaran menurun sejak \pm 2 minggu yang lalu. Pasien sebelumnya mengeluh panas \pm 2 hari yang lalu disertai dengan pendengaran yg menurun dan telinga yang berdengung. Riwayat muntah, batuk dan pilek disangkal. Riwayat berobat di rumah sakit dan diopname selama \pm 2 minggu. Penderita belum pernah menderita penyakit yang sama. Tidak ada riwayat penyakit sinusitis, alergi, anemia, autoimun dan penyakit sistemik lainnya. Penderita juga tidak pernah mengalami trauma dan menjalani operasi hidung sebelumnya.

Kata Kunci:tuli mendadak, sensorineural, audiometri

\begin{abstract}
Introduction: Sudden deafness or sudden sensorineural hearing loss (SSNHL) is defined as sensorineural hearing loss of more than $30 \mathrm{~dB}$ at three consecutive frequencies within 3 days of onset, often unilateral and idiopathic. Etiology of sudden deafness is still not known, but there are many theories put forward by the experts as a risk factor for sudden deafness. The prevalence of sudden deafness 5-30 per 100,000 people per year. Distribution of men and women almost equally, with the peak age of 50-60 years. Sudden deafness diagnosis is made based on history, physical examination and audiometry. Sudden deafness has three characteristics; acute, sensorineural hearing loss and unknown etiology. Additional characteristics may include vertigo, tinnitus and the absence of cranial nerve involvement. Management of sudden deafness include conservative therapy with multiple modalities.

Case: Patient male, 40 years, Bali, Hindu present with hearing loss since \pm 2 weeks ago. Patients previously complained of heat in the ear \pm 2 days ago accompanied by a downward hearing and ears. A history of vomiting, coughs and colds denied. History of treatment at the hospital and was hospitalized for \pm 2 weeks. Patients had never suffered from the same disease. No history of sinusitis, allergy, anemia, autoimmune and other systemic diseases. Patients also had never experienced trauma and underwent nasal surgery before.
\end{abstract}


Keywords:sudden deafness, sensorineural, audiometry.

\section{PENDAHULUAN}

Tuli mendadak atau sudden deafness atau sudden sensorineural hearing loss (SSNHL) didefinisikan sebagai kehilangan pendengaran sensorineural yang lebih dari $30 \mathrm{~dB}$ pada 3 frekuensi berturut turut dalam onset 3 hari, sering unilateral dan bersifat idiopatik. Etiologi tuli mendadak masih belum diketahui secara pasti namun terdapat banyak teori yang dikemukakan oleh para ahli sebagai faktor resiko terjadinya tuli mendadak. ${ }^{1}$

Prevalensi tuli mendadak 5-30 tiap 100.000 orang pertahun. Distribusi laki-laki dan perempuan hampir sama, dengan puncak usia 50-60 tahun. Insiden tuli mendadak di poli THT-KL RS. M. Djamil Padang pada satu tahun terakhir periode Agustus 2010 sampai Agustus 2011 berkisar 37 orang pasien. ${ }^{2}$ Diagnosis tuli mendadak ditegakkan berdasarkan anamnesis, pemeriksaan fisik dan audiometri. Tuli mendadak mempunyai tiga karakteristik yaitu bersifat akut, tuli sensorineural dan etiologi tidak diketahui. ${ }^{1,2}$

Karakteristik tambahan dapat berupa vertigo, tinitus dan tidak adanya keterlibatan saraf kranialis. Penatalaksanaan tuli mendadak meliputi terapi konservatif dengan beberapa modalitas. Penanganan harus dilakukan sedini mungkin karena penanganan yang terlambat akan menyebabkan tuli yang permanen..$^{1,2}$

Tuli mendadak atau sudden sensorineural hearing loss (SSNHL) didefinisikan sebagaibentuk sensasi subjektif kehilangan pendengaran sensorineural pada satu atau kedua telinga yang berlangsung secara cepat dalam periode 72 jam, dengan kriteriaaudiometri berupa penurunan pendengaran $\geq 30 \mathrm{~dB}$ sekurang-kurangnya pada 3 frekuensiberturut-turut, yang menunjukkan adanyaabnormalitas pada koklea, saraf auditorik, ataupusat persepsi dan pengolahan impuls pada korteks auditorik di otak. Jika penyebab tulimendadak tidak dapat diidentifikasi setelahpemeriksaan yang adekuat, disebut idiopathic sudden sensorineural hearing loss (ISSNHL). ${ }^{1}$

Ada empat teori utama yang mencoba menjelaskan penyebab tuli mendadak, yakni infeksi virus, kelainan vaskular, kerusakan membran intrakoklea, dan kelainan imunologi.

Keluhan pasien pada umumnya berupa hilangnya pendengaran pada satu sisi telinga saat bangun tidur. Sebagian besar kasus bersifat unilateral, hanya 1-2\% kasus bilateral. Kejadian hilangnya pendengaran dapat bersifat tiba-tiba, berangsur-angsur hilang secara stabil atau terjadi secara cepat dan progresif. Kehilangan pendengaran bisa bersifat fluktuatif, tetapi sebagian besar bersifat stabil. Tuli mendadak ini sering disertai dengan keluhan sensasi penuh pada telinga dengan atau tanpa tinitus; terkadang didahului oleh timbulnya tinitus. Selain itu, pada $28-57 \%$ pasien dapat ditemukan gangguan vestibular, seperti vertigo atau disequilibrium. ${ }^{1}$

Anamnesis yang teliti mengenai proses terjadinya ketulian, gejala yang menyertai, serta faktor predisposisi penting untuk mengarahkan diagnosis. Pada pemeriksaan fisik otoskopi tidak ditemukan kelainan pada telinga yang sakit. Pada pemeriksaan pendengaran (audiologi) didapatkan :

- Tes Penala : Rinne positif, Weber lateralisasi ke telinga yang sehat, Schwabach memendek. Kesan tuli sensorineural.

- Audiometri nada murni : Tuli sensorineural ringan sampai berat.

- Tes Tone Decay atau reflex kelelahan negatif. Kesan bukan tuli retrokoklea.

- Audiometri tutur : SDS (Speech Discrimination Score) kurang dari $100 \%$. Kesan tuli sensorineural

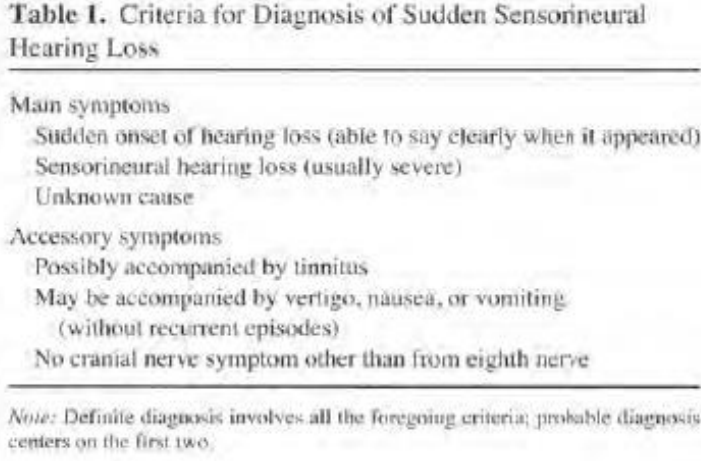

Gambar 1. Kriteria diagnosis SSNHL ${ }^{3}$ 
- Audiometri impedans : Timpanometri Tipe A (normal). Refleks stapedius ipsilateral negatif atau positif, sedangkan kontralateral positif. Kesan tuli sensorineural.

- BERA (pada anak) menunjukkan tuli sensorineural ringan sampai berat. Pemeriksaan ENG (elektronistagmografi) mungkin terdapat paresis kanal.

Pemeriksaan CT Scan dan MRI dengan kontras diperlukan untuk menyingkirkan diagnosis seperti neuroma akustik dan malformasi tulang temporal. Pemeriksaan arteriografi diperlukan untuk kasus yang diduga akibiat thrombosis. Pemeriksaan laboratorium dapat digunakan untuk memeriksa kemungkinan infeksi virus, bakteri, hiperlipidemia, hiperfibrinogen, hipotiroid, penyakit autoimun dan faal hemostasis. ${ }^{4,5}$

Karena sebagian besar penyebab tuli mendadak sensorineural adalah idiopatik, maka tuli mendadak harus dibedakan dengan kemungkinan etiologi lain seperti : infeksi bakterial (Meningitis, Labirinitis, Sifilis) dan viral (Herpes Simpleks, HIV, Mumps); penyakit autoimun (Eritematosis lupus sistemik); tumor ( Meningitis karsinoma, Schawanoma vestibular). ${ }^{1}$

Penatalaksanaan yang dilakukan antara lain pemberian kortikosteroid sistemik, kortikosteroid intratimpani, terapi oksigen hiperbarik.

Kortikosteroid Sistemik

Dewasa ini, standar pengobatan tuli mendadak adalah dengan tapering off kortikosteroid oral. Sebuah studi RCT (randomized controlled trial) membandingkan terapi steroid oral dengan plasebo pada 67 pasien, menunjukkan hasil perbaikan lebih signifikan pada kelompok pasien dengan terapi steroid oral dibandingkan kelompok pasien dengan plasebo $(61 \%$ vs. $32 \%, p<0,05)$. Untuk hasil pengobatan yang maksimal, dosis terapi prednison oral yang direkomendasikan adalah $1 \mathrm{mg} / \mathrm{kgbb} /$ hari dosis tunggal dengan dosis maksimum $60 \mathrm{mg} /$ hari selama 10-14 hari. Dosis ekuivalen prednison $60 \mathrm{mg}$ setara dengan metilprednisolon $48 \mathrm{mg}$ dan deksametason $10 \mathrm{mg}$. Sebuah data yang representatif menggunakan regimen pengobatan dengan dosis maksimum selama 4 hari diikuti tapering off $10 \mathrm{mg}$ setiap dua hari. Efek samping prednison meliputi insomnia, dizziness, kenaikan berat badan, berkeringat, gastritis, perubahan mood, fotosensitif, dan hiperglikemia.

Kortikosteroid Intratimpani

Steroid intratimpani yang biasa diberikan adalah deksametason atau metilprednisolon. Konsentrasi kortikosteroid yang digunakan bervariasi, sebagian besar studi menganjurkan deksametason $10-24 \mathrm{mg} / \mathrm{mL}$ dan metilprednisolon $30 \mathrm{mg} / \mathrm{mL}$ atau lebih. Efek samping terapi intratimpani yang harus diantisipasi adalah efek lokal, seperti otalgia, dizziness, vertigo, perforasi membran timpani, atau infeksi (otitis media).

Terapi Oksigen Hiperbarik

Terapi ini memberikan oksigen 100\% dengan tekanan lebih dari 1 ATA (atmosphere absolute). Terapi ini bertujuan untuk meningkatkan oksigenasi koklea dan perilimfe, sehingga diharapkan dapat menghantarkan oksigen dengan tekanan parsial yang lebih tinggi ke jaringan, terutama koklea yang sangat peka terhadap keadaan iskemik. Terapi oksigen hiperbarik diperkirakan memiliki efek yang kompleks pada imunitas tubuh, transpor oksigen dan hemodinamik, peningkatkan respons normal pejamu terhadap infeksi dan iskemia, serta mengurangi hipoksia dan edema. Menurut guideline AAO-HNS, terapi oksigen hiperbarik sebaiknya dilakukan dalam 2 minggu hingga 3 bulan dari saat diagnosis tuli mendadak. Pasien usia muda memberikan respons lebih baik dibandingkan pasien yang lebih tua (usia bervariasi antara 50-60 tahun). Terapi ini memiliki efek samping berupa kerusakan pada telinga, sinus dan paru akibat perubahan tekanan, miopi yang memburuk sementara, klaustrofobia, dan keracunan oksigen. ${ }^{6}$

Evaluasi fungsi pendengaran dilakukan setiap satu minggu selama satu bulan. Kallinen et al (1977) mendefinisikan perbaikan pendengaran pada tuli mendadak adalah sebagai berikut :

- Sangat baik, apabila perbaikan lebih dari $30 \mathrm{~dB}$ pada 5 frekuensi.

- Sembuh, apabila perbaikan ambang pendengaran kurang dari $30 \mathrm{~dB}$ pada frekuensi $250 \mathrm{~Hz}, 500 \mathrm{~Hz}$, 
$1000 \mathrm{~Hz}, 2000 \mathrm{~Hz}$ dan di bawah $25 \mathrm{~dB}$ pada frekuensi $4000 \mathrm{~Hz}$.

- Baik, apabila bila rerata perbaikan 10-30 dB pada 5 frekuensi.

- Tidak ada perbaikan, apabila terdapat perbaikan kurang dari $10 \mathrm{~dB}$ pada 5 frekuensi. ${ }^{7}$

Bila gangguan pendengaran tidak sembuh dengan pengobatan di atas, dapat dipertimbangkan pemasangan alat bantu dengar (hearing aid). Apabila dengan alat bantu dengar masih belum dapat berkomunikasi secara adekuat maka perlu dilakukan psikoterapi dengan tujuan agar pasien dapat menerima keadaan. ${ }^{1}$

Prognosis tuli mendadak tergantung pada beberapa faktor, yaitu usia, derajat gangguan pendengaran, metode pengobatan yang digunakan, saat memulai pengobatan, ada tidaknya gejala vestibular, dan faktor predisposisi lainnya. Usia lanjut, gangguan pendengaran sangat berat, dan adanya gejala vestibular subjektif dikaitkan dengan rendahnya tingkat kesembuhan. Usia lanjut, hipertensi, diabetes, dan hiperlipidemia berkaitan dengan disfungsi mikrovaskuler di koklea, yang merupakan faktor prognosis buruk. ${ }^{6,7}$

\section{KASUS}

Pasien laki-laki, berumur 40 tahun, beragama Hindu, suku Bali mengeluh mengalami pendengaran menurun \pm 2 minggu yang lalu. Pasien mengeluh panas \pm 2 hari yang disertai dengan pendengaran yg menurun dan telinga yang berdengung. Riwayat muntah, batuk dan pilek disangkal.Pasien pernahberobat di rumah sakit dan diopname selama \pm 2 minggu. Penderita belum pernah menderita penyakit yang sama. Tidak ada riwayat penyakit sinusitis, alergi, anemia, autoimun dan penyakit sistemik lainnya. Penderita juga tidak pernah mengalami trauma dan menjalani operasi hidung sebelumnya.Di lingkungan keluarga penderita tidak ada anggota keluarga lain yang menderita penyakit yang sama dengan penderita.Penderita adalah seorang wiraswasta, yang tidak merokok dan tidak minum alkohol.

Dari pemeriksaan fisik dan status generalis ditemukan dalam batas normal.

\section{Status lokalis THT :}

$\begin{array}{lcc}\text { Hidung } & \text { : dalam batas normal } & \\ \text { Tenggorok } & \text { : dalam batas normal } & \\ \text { Telinga } & \text { Kanan } & \text { Kiri } \\ \text { Sekret } & - & - \\ \text { Tuli } & + & + \\ \text { Tumor } & - & - \\ \text { Tinitus } & - & - \\ \text { Korpus Alienum } & - & - \\ \text { Vertigo } & - & -\end{array}$

Karena sebagian besar penyebab tuli mendadak sensorineural adalah idiopatik, maka tuli mendadak harus dibedakan dengan kemungkinan etiologi lain seperti :

- Infeksi Bakterial (Meningitis, Labirinitis, Sifilis) dan Viral (Herpes Simpleks, HIV, Mumps)

- Penyakit autoimun (Eritematosis lupus sistemik)

- Tumor ( Meningitis karsinoma, Schawanoma vestibular)

Dilakukan pemeriksaan tambahan

- Audiometri Nada Murni

$$
\begin{array}{ll}
A D: A C: 90 \mathrm{~dB} & A S: A C: 102,5 d B \\
B C: 77,5 d B & B C: 88,75 d B
\end{array}
$$

- Timpanometri

Tipe A Sinistra dan Dextra

Pasien didiagnosis dengan Aurikula Sinistra SNHL derajat sangat berat berat dan Aurikula Dextra SNHL derajat berat. Dilakukan penatalaksanaan Metyl cobalamin 1x1 tab, Metyl prednisolon $32 \mathrm{mg} \mathrm{x}$ 1 tab, Konsul Hiperbarik sebanyak 5 sesi, kontrol Poli THT-KL setelah terapi hiperbarik untuk evaluasi Audiologi dan KIE tentang istirahat yang cukup, sarapan pagi, dan membawa air minum dan permen untuk equalisasi.

\section{DISKUSI}

Penderita laki-laki, 40 tahun datang dengan keluhan utama pendengaran menurun sejak \pm 2 minggu yang lalu. Pasien sebelumnya mengeluh panas \pm 2 hari yang lalu disertai dengan pendengaran yg menurun dan telinga yang berdengung. Riwayat muntah, batuk dan pilek disangkal. Riwayat berobat di rumah sakit dan diopname selama \pm 2 minggu. Penderita belum pernah menderita penyakit yang sama. Tidak ada 
riwayat penyakit sinusitis, alergi, anemia, autoimun dan penyakit sistemik lainnya. Penderita juga tidak pernah mengalami trauma dan menjalani operasi hidung sebelumnya. Kasus sesuai dengan definisi tuli mendadak yaitu bentuk sensasi subjektif kehilangan pendengaran sensorineural pada satu atau kedua telinga yang berlangsung secaracepat dalam periode 72 jam, dengan kriteriaaudiometri berupa penurunan pendengaran $\geq 30 \mathrm{~dB}$ sekurang-kurangnya pada 3 frekuensiberturut-turut, yang menunjukkan adanyaabnormalitas pada koklea, saraf auditorik, ataupusat persepsi dan pengolahan impuls pada korteks auditorik di otak.

Dari pemeriksaan fisik didapatkan status present dan status general dalam batas normal. Status lokalisasi THT didapatkan hidung dan tenggorok dalam batas normal. Pada pemeriksaan telinga didapatkan tuli (+) D/S, sedangkan sekret, tumor, tinitus, korpus alienum dan vertigo (-).

Diagnosa ditegakkan berdasarkan anamnesa, pemeriksaan fisik serta pemeriksaan penunjang berupa audiometri nada murni dan timpanometri. Diagnosis kerja berupa Tuli Mendadak atau SSNHL (Sudden Sensorineural Hearing Loss) D/S. Kasus sesuai dengan diagnosis tuli mendadak yang pada pemeriksaan fisik telinga mengalami penurunan fungsi pendengaran. Pemeriksaan audiometri nada murni dan timpanometri juga mengarah pada diagnosis tuli mendadak.

Penatalaksaan pasien yang diberikan berupa Metyl cobalamin 1x1 tab, Metyl prednisolon $32 \mathrm{mg} \times 1$ tab dan konsul Hiperbarik sebanyak 5 sesi. KIE yang diberikan berupa kontrol Poli THT-KL setelah terapi hiperbarik untuk evaluasi Audiologi. Pasien dianjurkan Istirahat yang cukup, sarapan pagi, membawa air minum dan permen untuk equalisasi saat melakukan terapi hiperbarik. Penatalaksaan dan KIE yang diberikan pasien sudah tepat sesuai dengan tinjauan pustaka. Prognosis pasien diharapkan baik mengingat pasien tidak memiliki faktor predisposisi yang dapat menghambat hasil terapi.

\section{DAFTAR PUSTAKA}

1. Novita Stevani, Yuwono Natalia. Diagnosis dan Tatalaksa Tuli mendadak. Continuing Medical Education IDI. RSUD Landak. Ngabang. 2013.

2. Munilson Jacky, Yurni. Diagnosis dan Penatalaksaan Tuli Mendadak. Departemen THT-KL Rumah Sakit Dr. M. Djamil. Padang. 2011.

3. Harada $H$, Kato S. Prognosis for Sudden Sensorineural Hearing Loss: A Retrospective Study Using Logistical Regression Analysis. Int Tin Journal. 2005; 11(2): 115-8.

4. Ohno Kazuchika, Noguchi Yoshihiro, Kawashima Yoshiyuki, Yagisitha Kazuyoshi, Kitamura Ken. Secondary Hyperbaric Oxygen Therapy for Idiopathic Sudden Sensorineural Hearing Loss in the Subacute and Chronic Phases. J Med Dent Sci. Tokyo. 2010.

5. J Robert et al. Clinical Practice Guideline : Sudden Hearing Loss. American Academy of Otolaringology - Head and Neck Surgery. Detroit. 2012.

6. Mansjoer, A. Dkk. Kapita Selekta Kedokteran, edisi ke3, Jilid pertama, penerbit Media Aesculapius, FKUI, Jakarta. 2001.

7. Eisenman DJ, Arts HA. Effectiveness of treatment for sudden sensorineural hearing loss. Arch. Otolaringology Head and Neck Surgery. 2000. 